\title{
Mouse Leydig Cell Tumor
}

National Cancer Institute

\section{Source}

National Cancer Institute. Mouse Leydig Cell Tumor. NCI Thesaurus. Code C134947.

A Leydig cell tumor that occurs in a mouse. 